\title{
Accounting Information System, Internal Control System, Human Resource Competency and Quality of Local Government Financial Statements in Indonesia
}

\author{
Anna SUMARYATI ${ }^{1}$, Eka PRAPTIKA NOVITASARI ${ }^{2}$, Zaky MACHMUDDAH $^{3}$
}

Received: August 01, 2020 Revised: September 06, 2020 Accepted: September 10, 2020

\begin{abstract}
This study seeks to determine the effect of the application of accounting information system (AIS), internal control system, and human resource (HR) competency on the quality of local government financial statements (FS). This study uses agency theory and compliance theory. Agency theory is used to explain that there is a link between the society as the principal and the government as the agent. Compliance theory is a theory, which states that every agency is obliged to comply with regulations because the law-drafting authority has the right to dictate behavior. The population in this study were employees of the financial division of local government organizations in one of the districts in Central Java, Indonesia. The total samples in this study was 106 respondents. The data used are primary data taken from distributing questionnaires to respondents. The method of analysis used to test the hypothesis was multiple linear regression analysis. The results of hypothesis testing indicate that HR competency has an effect on the quality of FS; however, the application of AIS and internal control system has no effect on the quality of FS. The implication of this research underlines the importance of HR competency to improve the quality of local government FS.
\end{abstract}

Keywords: Financial Statements, Accounting Information System, Internal Control System, Human Resource Competency

JEL Classification Code: G21, G24, G29

\section{Introduction}

The core issue in this research is that there are yet local government organizations in Central Java, Indonesia, that have not performed fair FS without exception or excellent FS, even though good governance is the demand of society today. This has made the government realize the importance

${ }^{1}$ First Author. Lecturer, Accounting Department, Faculty of Economic and Business, University of Dian Nuswantoro, Indonesia.

Email: anna.sumaryati@dsn.dinus.ac.id

${ }^{2}$ Accounting Department, Faculty of Economic and Business, University of Dian Nuswantoro, Indonesia.

Email:212201603103@mhs.dinus.ac.id

${ }^{3}$ Corresponding Author. Lecturer, Accounting Department, Faculty of Economic and Business, University of Dian Nuswantoro, Indonesia [Postal Address: Jl. Nakula I No. 5-11, Semarang, Central Java, 50131, Indonesia] Email: zaky.machmuddah@dsn.dinus.ac.id

(C) Copyright: The Author(s)

This is an Open Access article distributed under the terms of the Creative Commons Attribution Non-Commercial License (https://creativecommons.org/licenses/by-nc/4.0/) which permits unrestricted non-commercial use, distribution, and reproduction in any medium, provided the original work is properly cited. of public accountability, be it at the central government or local governments. Accountability is important for the transformation of information for public administration or accounting for the continuity of financial management of the central government and local governments (Saleh, et al., 2020; Evicahyani \& Setiawina, 2016). Publishing FS used as the foundation in decision-making is an obligation of the central and local governments (Mahaputra \& Putra, 2014). The criteria that must be met in a financial statement include: relevance, assessable or comparable, reliable and understandable in order to create a quality statement (Tawakal \& Suparno, 2017).

Based on Government Regulation No.12 of 2019, regional financial management is all activities including planning, budgeting, implementation, administration, reporting, accountability, and monitoring of FS. Based on Government Regulation No. 71 of 2010, regional government FS (henceforward abbreviated as LKPD) have seven components, namely, budget realization statements, changes in excess budget balance statements, balance sheets, operational statements, cash flow statements, changes in 
equity statements, and notes on FS. FS must be guided by Government Accounting Standards, to be henceforward abbreviated as SAP, which is also a guideline in holding legal power with the aim of developing noteworthy information on government FS in Indonesia (Mahaputra \& Putra, 2014). Disclosing information regarding the financial position, cash flow, budget realization and financial performance of a reporting institution that is useful for every user of FS to make decisions is the goal of a financial statement (Shintia \& Erawati, 2017).

This study uses agency theory and compliance theory to explain the relationship between the societies who will demand accountability to the government as the agent. Government, to ensure accountability, provides, reports, and explains all activities and those that have become the responsibility of the government to the society (Shintia \& Erawati, 2017). Compliance theory is concerned with how to socialize in order to influence obedient behavior of a person or individual. The compliance of a reporting agency to present an accountability statement in the form of FS is essential to carry out compliance toward the presentation of information in FS based on SAP (Shintia \& Erawati, 2017).

Factors that support the quality of FS are the AIS that is prepared to create information in the form of financial information required by external or internal parties of an agency or institution. The AIS is a sub-system or part of an organization that has an obligation to provide financial information to support management when making decisions (Tawakal \& Suparno, 2017). The use of a regional financial AIS is a system application of grouping, classifying, recording and processing a local government financial activity in FS in information that will be used in making FS decisions (Shintia \& Erawati, 2017).

Another factor that supports an excellent financial statement is the internal control system. This is where the system is useful to support the appropriate stand for the realization of effectiveness and efficiency in the accounting process, which aims to achieve the reliability of FS (Hardiningsih, et al., 2020). That way the application of an internal control system is able to achieve reliability, objectivity of information, and inhibits irregularity and simplifies the financial reporting audit process (Mahaputra $\&$ Putra, 2014). The internal control system is very important because the quality of FS of a company depends on whether or not the system is good (Bahtiar, 2013).

Human Resource (HR) competency for the management of a financial statement is a key factor for the creation of financial integrity. HR competency is the ability of HR to carry out work and responsibilities that have been given through capital of competent training, education, and experience. Qualified and experienced HR can understand accounting logic well, therefore financial integrity can be generated (Evicahyani \& Setiawina, 2016).

This is supported by a research done by Zulfah et al. (2017) stating that the AIS affects the quality of FS at Regional Work Unit (henceforward abbreviated as SKPD) Aceh Utara Regency. Also, this is in line with research conducted by Juwita (2013), Tawakal and Suparno (2017) and Astrawan, et al. (2016), which stated that the application of an AIS has an effect on the quality of FS. However, these study results are contrary to those of Wardani and Andriyani (2017), which stated that the use of the regional financial AIS has no significant effect on the quality of local government FS.

The research conducted by Husna et al. (2013) states that the quality of financial reporting can be improved by internal control. This is in line with the research by Bahtiar (2013), Herawati (2014), Shintia and Erawati (2017), Mutiana et al. (2017), Mahaputra and Putra, (2014), and Astrawan et al. (2016) that shows that there is an influence of the internal control system on the quality of FS. However, this study is not agree with Yendrawati (2013) who stated that internal control has no effect on the quality of FS.

The research conducted by Mutiana et al. (2017) stated that the quality of HR has an effect on FS. This is in line with the research by Astrawan et al. (2016), Tawakal and Suparno (2017) and Evicahyani and Setiawina (2016), which state that human resource competency affects the quality of regional FS. However, this study is not in line with the research conducted by Husna (2013), which stated that there is no significant effect of the quality of HR on the value of regional financial reporting information.

The variety of research findings and phenomena described here makes this investigation essential. The object of this research is the regional government organization of Grobogan Regency and it was carried out in 2020. So, the research question is whether the application of AIS, internal control system, and human resource competency affects the quality of FS of Grobogan Regency regional government.

\section{Literature Review}

\subsection{Agency Theory}

Jensen and Meckling (1976) mentioned that agency theory describes the contractual relationship between agents (company managers) and principals (company owners). This theory is used to explain that there is a link between the society as the principal and the government as the agent. The government (agent) as the party holding the trust of the people who is obliged to provide an accountability, presentation, reporting and disclosure of all activities, which 
are the responsibility of the government to the society (the principal) as the party giving the trust has the right to demand accountability. Agency theory views that its implementation has very different needs between principals and agents, resulting in disputes over an interest or agency problem. In order to suppress a problem, it is necessary to monitor what the principal is doing on the agent. FS are a means of monitoring the efforts of prevention if there is agency cost (Shintia \& Erawati, 2017).

The problem explaining agency and financial practice for public sector organizations is a design based on agency theory. In a financial statement, the government, which acts like an agent, has an obligation to disclose information that benefits each user of financial information and also the society who has a role as principal to evaluate accountability and make decisions, whether political, social and economic decisions, directly or indirectly by using its representative. The agency relationship in a democratic government is described by the relationship between a government and each user of financial information.

\subsection{Compliance Theory}

Compliance theory is a theory that states that every agency is obliged to comply with regulations because the law-drafting authority has the right to dictate behavior (normative through legitimacy/normative commitment through legitimacy). According to Sutinen and Kuperan (1999), from the perspective of economics, compliance theory has many perspectives. Neoclassical perspective views the rules that exist in the business world as an obstacle to obtaining maximum business profit. The theory of compliance has been researched in the social sciences, especially in the fields of sociology and psychology, which focuses more on the need for a socialization process in influencing the obedience behavior of an individual.

Compliance theory is divided into two perspectives, namely, instrumental and normative perspectives. The instrumental perspective is that of an individual who is wholly driven by self-interest and responses to changes in incentives, while the normative perspective is one that relates to morals and is opposed to self-interest. Based on the normative perspective, the theory of compliance should be applied in accounting.

Compliance theory emphasizes the influence of a socialization process to affect the compliance integrity of a person or the individual itself. Viewed from the normative perspective in compliance theory, this theory can be applied to aspects of accounting. The compliance of an agency or reporting institution to perform an accountability report in the form of a financial statement is a definite matter to fulfill compliance toward the presentation of financial statement information based on SAP (Shintia \& Erawati, 2017).

\subsection{Hypothesis Development}

\subsubsection{The Effect of the Application of AIS on the Quality of FS}

An AIS is defined as a collection of resources, namely, humans and equipment, which are formed to change financial data and other data in the form of information. The financial information is then discussed with decision makers. AIS carries out the process using manual system or by using computers (Bodnar \& Hopwood, 2004). An AIS is a system that compiles data and transactions in order to provide useful information in the design, supervision and operation of a business (Tawakal \& Suparno, 2017). In other word, the better an agency's AIS, the better the quality of the FS it produces. This is in line with $\mathrm{Ha}$ (2020) who states that information system factors have a positive effect on operational performance, meaning that if the AIS factor is getting better, operational performance will increase.

This is in line with the theory of compliance; there is a link between the use of information system and the quality of local government FS where in the application of the information system employees must comply with existing regulations so that there are no violations of the use of information system. According to Zulfah et al. (2017) the AIS has a significant effect on the quality of a financial statement in the SKPD of North Aceh Regency, this is in line with research conducted by Tawakal and Suparno (2017) and Juwita (2013) that the application of information systems accounting affects the quality of SKPD FS in Banda Aceh City. The same research conducted by Astrawan, et al. (2016) stated that the AIS had a significant effect on the promptness of local government financial reporting. Therefore, the first hypothesis of the study is:

\section{H1: The application of the AIS affects the quality of FS}

\subsubsection{The Effect of Internal Control System on the Quality of FS}

The internal control system is a procedure that is integral to steps or activities carried out on an ongoing basis by leaders and employees in order to create belief that is satisfactory enough for the realization of organizational goals with effective and efficient activities, reliability of financial One of the factors that affect the financial performance of a local government is internal control. The accounting system requires internal control because the accounting system as an information system is a subject that often has problems either intentionally or unintentionally (Husna et al., 2017). If an internal control system is good, accounting procedures can be easily directed, supervised, and detected in the event 
of fraud so that FS achieve their objectives and present reliable and excellent financial information (Yendrawati, 2013).

Compliance theory supports the relationship between the internal control system and the quality of local government FS where internal control is intended to provide assurance that LKPD must be fairly disclosed based on the basis of accounting in Indonesia, adherence to existing laws, and regulations and enhancement in operating activities effectively and efficiently. This is reinforced by a research conducted by Tawakal and Suparno (2017), which stated that the internal control system affects the quality of FS of SKPD the City of in Banda Aceh. In line with research conducted by Shintia and Erawati (2017), Husna et al. (2017), Mutiana et al. (2017), Mahaputra and Putra (2014), Bahtiar (2013), dan Astrawan et al. (2016) that internal control affects the quality of local government FS. Therefore, the second hypothesis of the study is:

\section{H2: The internal control system affects the quality of FS.}

\subsubsection{The Effect of HR Competency on the Quality of FS}

Human resource competency is the expertise of HR that is useful for carrying out work and obligations that have been entrusted with capital of competent training, education and experience. Employees who have minimal knowledge of their duties and functions, as well as problems encountered in the data compilation process can also affect the presentation of FS (Mutiana et al., 2017).

Agency theory supports the relationship between the quality of HR and the quality of local government FS; agency theory is used to explain that there is a relationship between the society as the principal and the government as the agent, so that good quality HR are needed in all government agencies to fulfill the needs of the society (principals) and provide an accountability, presentation, reporting and disclosure of activities that are their responsibility to the society, such as producing reliable local government FS. This means that the better the quality of the HR the better the quality of the FS.

This is reinforced by research conducted by Shintia and Erawati (2017), Tawakal and Suparno (2017), Astrawan et al. (2016), Mutiana et al. (2017) and Evicahyani and Setiawina (2016) stating that human resource competency affects the quality of FS. Therefore, the third hypothesis of this research is:

H3: Human resource competency affects the quality of FS.

\section{Research Method}

The population in this study were employees of the financial division of regional government organizations in Grobogan Regency, Indonesia. The selection of the object of this study was based on the consideration that Grobogan Regency is a district in the Province of Central Java, Indonesia, which is able to obtain Unqualified Opinion (WTP) for its FS within four consecutive years, and the selection of the agencies in Grobogan Regency was done based on two reasons: first, the agency concerned is a regional government work unit, which means that it is involved in managing, compiling, and reporting government FS; and second, they are also some of the users of these FS.

The determination of the sample in this study was based on the purposive sampling method, namely, the sample was determined on the basis of judgment; therefore, it is called judgment sampling. The criteria used to take this sample were: 1) employees with the status of civil servants and noncivil servants, 2) playing a role in preparing FS at related agencies, 3) minimum length of work of 1 (one) year.

The type of data used in this research is primary data, data obtained from sources directly collected in a certain way and is directly related to the research problem studied. The questionnaire contains questions about the accounting information system, internal control system and HR on the quality of FS. The measurement of the questionnaire in this study is a 5-point Likert scale.

Data was collected through the questionnaire distributed directly to the respondents - employees and staff in the accounting or finance division of the regional government of Grobogan Regency, Central Java province, Indonesia. Once answered, the questionnaire was collected directly from the institution. The formula used in testing the effect of the independent variable on the dependent variable is:

QUALITY $=\alpha+\beta 1$ AIS $+\beta 2 \mathrm{ICS}+\beta 3 \mathrm{HR}+\mathrm{e}$

Information:

Quality $=$ Quality of Regional FS

$\alpha=$ Constant

AIS = Application of Accounting Information System

ICS $=$ Internal Control System

$\mathrm{HR}=$ Human Resource Competency

$\beta 1-\beta 3=$ Multiple regression coefficients

$\mathrm{e}=$ error term

\section{Results}

The object of this research is the government service of Grobogan Regency, Central Java Province, Indonesia. 
The number of Regional Government Organizations (henceforward abbreviated as OPDs) in Grobogan Regency is 29 offices and agencies, while 20 offices were researched. The sample used is the judgment sampling method based on the criteria, namely, the OPD of Grobogan Regency officials who work in an accounting or finance department. Based on observations and interviews with several respondents, each office has approximately six employees and staff in the accounting or finance department. Henceforth, researchers spread out 115 questionnaires. There were three respondents who filled incomplete questionnaires, while six respondents did not return the questionnaire, so there were 106 questionnaire completed.

Based on the data, $34 \%$ of the respondents are $41-50$ years old. From a survey conducted by female employees and staff in the financial sector, there are more than $63.2 \%$ of male employees and staff. $75.5 \%$ have been civil servants. Most of the employees or staff $(36.8 \%)$ have worked for more than 15 years.

Regression analysis was used to see how the influence of the variables of the application of AIS, ICS and financial HR competencies on the variable of FS quality. The following shows the results of multiple linear regression tests:

The determinant coefficient test $\left(\mathrm{R}^{2}\right)$ is practical in seeing the extent to which a dependent variable is able to explain the independent variable. To find out the results of the determinant coefficient $\left(\mathrm{R}^{2}\right)$ test; see the model summary table in the Adjusted R Square column. The following is a research summary model table:

Table 2 shows that the Adjusted R Square value in the model summary table is 0.085 or $8.5 \%$. It can be concluded that the variable of FS quality can be explained by all independent variables by $8.5 \%$. While the remaining 91.5 is explained by other variables, which are not examined. The results of the f test can be seen from the Anova table, if the significance is less than 0.05 , together the independent variables have an effect on the dependent variable. Table 3 shows the $\mathrm{F}$ test results.

From the table above it can be seen that the significance value of $0.007<0.05$, it means that all independent variables as a whole and together have an effect on the dependent variable. The $\mathrm{t}$ test is to find out how far an independent variable individually explains the variation in the dependent variable and is used to determine whether there is an effect of each independent variable individually. To find out the results of the $\mathrm{t}$ test, it can be seen in the coefficient table in the Sig. where if the significance is less than 0.05, the hypothesis is accepted, which means that the independent variable partially has an influence on the dependent variable. Here is the $t$ test table:

Table 1: Heteroskedasticity Test

\begin{tabular}{|c|c|c|c|c|c|}
\hline \multirow{2}{*}{ Model } & \multicolumn{2}{|c|}{ Unstandardized Coefficients } & \multirow{2}{*}{$\begin{array}{c}\text { Standardized Coefficients } \\
\text { Beta }\end{array}$} & \multirow{2}{*}{$\mathbf{t}$} & \multirow{2}{*}{ Sig } \\
\hline & B & Std. Error & & & \\
\hline \multirow{4}{*}{$\begin{array}{l}\text { (Constant) } \\
\text { Application of AIS } \\
\text { ICS } \\
\text { HR Competency }\end{array}$} & 4.006 & 3.940 & - & 1.017 & 0.312 \\
\hline & 0.003 & 0.054 & 0.006 & 0.059 & 0.953 \\
\hline & -0.244 & 0.141 & -0.171 & -1.728 & 0.087 \\
\hline & 0.103 & 0.069 & 0.148 & 1.502 & 0.136 \\
\hline
\end{tabular}

a. Dependent variable: FS quality

Table 2: Autocorrelation Test

\begin{tabular}{|l|c|c|c|c|c|}
\hline Model & $\mathbf{R}$ & $\mathbf{R}$ Square & Adjusted R Square & Std. Error of the Estimate & Durbin-Watson \\
\hline 1 & $0.334^{\mathrm{a}}$ & 0.112 & 0.085 & 3.829 & 1.481 \\
\hline
\end{tabular}

a. Predictors: (Constant), HR Competency, ICS, Application of AIS

b. Dependent variable: FS quality

Table 3: F Test

\begin{tabular}{|c|l|c|c|c|c|c|}
\hline \multicolumn{2}{|l|}{ Model } & Sum of Squares & df & Mean Square & F & Sig. \\
\hline \multirow{4}{*}{1} & Regression & 187.801 & 3 & 62.600 & 4.269 & $0.007^{\text {a }}$ \\
\cline { 2 - 7 } & Residual & 1495.821 & 102 & 14.665 & & \\
\cline { 2 - 7 } & Total & 1683.623 & 105 & & & \\
\hline
\end{tabular}

a. Predictors: (Constant), HR Competency, ICS, Application of AIS

b. Dependent variable: FS quality 
Table 4: $\mathrm{t}$ Test

\begin{tabular}{|l|c|c|c|c|c|}
\hline \multirow{2}{*}{ Model } & \multicolumn{2}{|c|}{ Unstandardized Coefficients } & Standardized Coefficients & \multirow{2}{*}{ Sig } \\
\cline { 2 - 5 } & B & Std. Error & Beta & 3.024 \\
\hline \multirow{2}{*}{$\begin{array}{l}\text { Application of AIS } \\
\text { ICS }\end{array}$} & 22.058 & 7.295 & - & 0.003 \\
\cline { 2 - 5 } HR Competency & 0.194 & 0.101 & 0.185 & 0.058 \\
\cline { 2 - 5 } & 0.202 & 0.261 & 0.074 & 0.775 \\
\cline { 2 - 6 } & 0.297 & 0.127 & 0.222 & 2.333 & 0.022 \\
\hline
\end{tabular}

a. Dependent variable: FS quality

Based on the table above, the regression equation obtained is as follows:

$$
\mathrm{Y}=22.058+0.194 \mathrm{AIS}+0.202 \mathrm{ICS}+0.297 \mathrm{HR}+\mathrm{e}
$$

\subsection{The Effect of AIS Application on the Quality of Regional FS}

Based on Table 4, the level of significance for the AIS variable is 0.058 , meaning that the application of the regional financial AIS has no effect on the quality of the regional government FS of Grobogan Regency. Thus, the first hypothesis, which states that the application of AIS affects the quality of FS, is rejected. The results of this study are not in accordance with the compliance theory, which explains that, in the application of the accounting information system, employees must comply with the existing regulations so that there are no violations of the use of information system.

Assessing from the results of respondents' answers to the variables of the application of the regional financial accounting information system, the average level of achievement of the respondents in the variable of application of AIS has an achievement level above the average of $49 \%$ and has a value below the average of $51 \%$. Although in view of the OPDs have done it well, in reality local government organizations are not yet fully able to prove that they are capable of implementing AIS properly.

It can be seen from the results of the answers of respondents who have the lowest average score, it is stated that the OPD of Grobogan Regency have not fully classified the transactions that have occurred properly. This shows that the government has not fully utilized the regional financial AIS properly. Although the application of the AIS at OPD has not been implemented properly, the quality of FS in the OPD of Grobogan Regency has received an unqualified opinion by the BPK (Audit Board of the Republic of Indonesia), which means that the FS of the Grobogan Regency regional government are of good quality. It can be concluded that the application of the AIS has no effect on the quality of FS in the OPD of Grobogan Regency. The results of this research hypothesis testing support the research conducted by Wardani and Andriyani (2017) that stated that the application of the AIS has no effect on the quality of regional FS.

\subsection{The Effect of Internal Control System on the Quality of Regional FS}

The results of this study indicate that the internal control system has no effect on the quality of the regional government FS of Grobogan Regency, this can be seen from Table 4, which shows that the level of significance of the internal control system variable is 0.440 . Thus, the second hypothesis, which states that the internal control system affects the quality of FS, is rejected. The results of this study are not in accordance with the compliance theory, which explains that in the application of the internal control system, employees must comply with the existing regulations so that there are no violations.

It can be seen from the data of the respondent's answer for the internal control system variable, where the average achievement level of the internal control system variable, which is above the average is $36 \%$, while those below the average are $64 \%$. Although in perception, the OPDs have done it as well as possible, the reality is that OPDs have not been able to prove that they are not yet fully capable of implementing the internal control system properly. It can be seen from the results of the respondents' answers that have the lowest average score, it is stated that the OPDs of Grobogan Regency have not fully implemented the proper separation of authority in carrying out an activity or transaction. This shows that the Grobogan Regency government has not fully utilized the internal control system properly. Although the internal control system in OPD has not been implemented properly, the quality of FS in the local government of Grobogan Regency has received an unqualified opinion by the BPK, which means that the FS of the Grobogan Regency regional government are of good quality. This study is in accordance with the research by Yendrawati (2013) that found that the internal control system do not have a significant effect on the quality of FS produced by the agency's accounting system. 


\subsection{The Effect of HR Competency on the Quality of Regional FS}

The information presented in Table 4 shows that the significance value for the variable human resource competency is 0.022 , meaning that human resource competency affects the quality of local government FS. Thus, the third hypothesis stating that human resource competency has an effect on the quality of FS is accepted. It can be seen from the data of the respondent's answer for the internal control system application variable, where the average respondent's level of achievement for the internal control system variable is in the good category.

The relationship between human resource competency and agency theory, namely, HR (Grobogan Regency government's employees) as agents who must carry out contracts in the form of laws and regulations that have been made by the principal, namely the official authorized to make regulations in the public sector. Where in carrying out duties as a good government service employees must train competency or ability and add insight into the field of accounting both in theory and practice as well as manually or computerized.

The agency relationship has different purposes between the principal and the agent. For the principal, the official who is authorized to make regulations in the public sector has the objective of encouraging the creation of good governance with statements produced by agents or government service employees. While the agent's goal is to get rewarded for the efforts made as an employee who obeys the existing regulations. In the human resource competency variable, it has the highest average value of 4.66, indicating that the HR in Grobogan Regency OPD have quality or competent resources to prepare FS in accordance with applicable standards and regulations.

The results of testing the research hypothesis support Mutiana et al. (2017), Astrawan et al. (2016), Tawakal and Suparno (2017), dan Evicahyani and Setiawina (2016), which stated that human resource competency affects the quality of regional FS.

\section{Conclusion}

Based on the results of data analysis and hypothesis testing, it can be concluded that the human resource competency has an effect on the quality of FS in the local government of Grobogan Regency. However, the application of AIS and internal control system have no effect on the quality of FS in the local government of Grobogan Regency. The limitation of this study is that the adjusted $\mathrm{R}$ square value is very small $(8.5 \%)$. So, the suggestion for future research is a modification of the model and other variables to better support the findings. The implication of this research is to underline the importance of the quality of government FS because government FS must be published and accountable to the public.

\section{References}

Astrawan, K. P., Wahyuni, M. A., \& Herawati, N. T. (2016). The Influence of Accounting Information System, Human Resource Capacity, Internal Control and Financial Supervision of Local Governments on the Promptness of Regional Government Financial Reporting at SKPD Buleleng Regency. E-Journal SI AK Universitas Pendidikan Ganesha, 6(3), 1-13.

Evicahyani, S. I., \& Setiawina, N. D. (2016). Analysis of Factors Affecting the Quality of Regional Government Financial Statements of Tabanan Regency. E-Journal Economic and Business Universitas Udayana 5(3), 403-428.

Ha, V. D. (2020). Impact of Organizational Culture on the Accounting Information System and Operational Performance of Small and Medium Sized Enterprises in Ho Chi Minh City. Journal of Asian Finance, Economics and Business, 7(2), 301308. https://doi.org/10.13106/jafeb.2020.vol7.no2.301

Hardiningsih, P., Udin, U., Masdjojo, G. N., \& Srimindarti, C. (2020). Does Competency, Commitment, and Internal Control Influence Accountability? Journal of Asian Finance, Economics and Business, 7(4), 223-233. https://doi.org/10.13106/ jafeb.2020.vol7.no4.223

Herawati, H. (2014). The Effect of Internal Control System on the Quality of Financial Statements. Journal SIKAP, 11(1), 49.

Husna, F. (2013). The Effect of Human Resources Quality, Financial Control, and Government Internal Control Systems on the Value of Government Financial Reporting. Accounting Journal, 1(2), 1-20.

Husna, N., Rasyidin, M., \& Zairinah, A. (2017). The Effect of the Government's Internal Control System on the Quality of Financial Statements at the Government North Aceh Regency. Journal of Accounting and Development, 3(2), 107-114.

Jensen, M. C., \& Meckling, W. H. (1976). Theory of the Firm: Managerial Behavior, Agency Cost and Ownership Structure. Journal of Financial Economics, 3, 305-360.

Juwita, R. (2013). The Effect of the Implementation of Government Accounting Standards and Accounting Information Systems on the Quality of Financial Statements. Trikonomika, 12(2), 201-214.

Mahaputra, I. P. U. R., \& Putra, I. W. (2014). Analysis of Factors Affecting the Quality of Local Government Financial Reporting Information. E-Journal Accounting Universitas Udayana, 2, 400.

Mardani, L. B., \& Suhartono, E. (2019). Analysis of the Influence of Financial Information Systems and Internal Control Systems on the Quality of Local Government Financial Statements (Study at the Government Service of Semarang City). Journal of Accounting and Applied Accounting, 10, 177-188.

Mutiana, L., Diantimala, Y., \& Zuraida, Z. (2017). The Influence of Internal Control Systems, Information Technology, Quality of 
Human Resources and Organizational Commitment on Quality of Financial Statements (Study on Satker within the Ministry of Religion, North Aceh Regency). Darussalam Economic Perspective Journal, 3(2), 151-167.

Saleh, C., Hayati, H., Sumartono, S., Pratiwi, N. R. (2020). Moderating of Religiosity on Reward and Engagement: Empirical Study in Indonesia Public Service. Journal of Asian Finance, Economics and Business, 7(6), 287-296. https://doi. org/10.13106/jafeb.2020.vol7.no6.287

Setyowati, L., Isthika, W., \& Pratiwi, R. D. (2016). Factors Affecting the Quality of Semarang City Government Financial Statements. Performance, 20(2), 179-191.

Shintia, C. I. A. P., \& Erawati, N. M. A. (2017). The Influence of HR Quality, Information Systems, Internal Control and Organizational Commitment on the Quality of Financial Statements. Journal of Accounting at Udayana University, 2 (2), 1186-1205.

Sutinen, J. G., \& Kuperan, K. (1999). A socio-economic theory of regulatory compliance. International Journal of Social Economics, 174-193.
Tawakal, I., \& Suparno. (2017). The Influence of the Application of Accounting Information System, Internal Control System and Human Resource Competency on the Quality of Financial Statements of Regional Work Units in the City Government of Banda Aceh. Accounting Economics Student Scientific Journal, 2(4), 125-135.

Wardani, D. K., \& Andriyani, I. (2017). The Effect of Human Resources Quality, Utilization of Information Technology, and Internal Control Systems on the Reliability of Village Government Financial Reporting in Klaten Regency. Accounting Journal, 5(2), 88-98.

Yendrawati, R. (2013). The Influence of Internal Control Systems and Human Resource Capacity on the Quality of Information on Financial Statements with External Factors as Moderating Variables. Accounting and Auditing Indonesia Journal, 17(2), 166-175.

Zulfah, I., Wahyuni, S., \& Nurfaza, A. (2017). The Effect of Accounting Information System on the Quality of Financial Statements at SKPD North Aceh Regency. Journal of Accounting and Development, 3 (November), 46-57. 